7. Dennis T. A. Interactions between emotion regulation strategies and affective style: Implications for trait anxiety versus depressed mood / T. A. Dennis // Motivation and Emotion. - 2007. - Vol. 31(3). - P. $200-207$.

8. Egner T. Cognitive control mechanisms resolve conflict through cortical amplification of task-relevant information / T. Egner, J. Hirsch // Nature Neuroscience. - 2005. - Vol. 8(12). - P. 1631-1633.

9. Fisher H. Age-differential patterns of brain activation during perception of angry faces / H. Fisher, J. Sandblom, J. Gavazzeni, P. Franson, C. I. Wright, L. Bäckman. - Neuroscience Letters. - 2005. - Vol. 386(2). - P. $99-104$.

10. Jordan K. Women and men exhibit different cortical activation patterns during mental rotation tasks / K. Jordan, T. Wüstenberg, H.-J. Heinze, M. Peters, L. Jäncke // Neuropsychologia. - 2002. - V. 40. - P. 2397-2408.

11. Näätänen R. Memory-based or afferent processes in mismatch negativity (MMN): a review of the evidence / R. Näätänen, T. Jacobsen, I. Winkler // Psychophysiology. - 2005. - Vol. 42(1). - P. 25-32.

12. Pizzagalli D. A. Coupling of theta activity and glucose metabolism in the human rostral anterior cingulate cortex: An EEG/PET study of normal and depressed subjects / D. A. Pizzagalli, T. R. Oakes, R. J. Davidson // Psychophysiology. - 2003. - Vol. 40. - P. 939-949.

13. Speck O. Gender differences in the functional organization of the brain for working memory / O. Speck, T. Ernst, J. Braun, C. Koch, E. Miller, L. Chang // Neuroreport. - 2000. - V. 11. - P. 2581-2585.

Журавлев Александр, Гошко Людмила, Бурбан Лилия. Анализ интенсивности корковой электрической активности в тета-диапазоне ЭЭГ в условиях формирования фазических эмоций разной валентности в зависимости от пола исследуемых. В статье приведены результаты исследования корковой электрической активности в тета-диапазоне ЭЭГ при формировании фазических эмоций разного знака в зависимости от пола исследуемых. Показано наличие отличительных особенностей в общей организации коркового электрогенеза у мужчин и женщин при индуцировании фазических эмоций, которые заключаются в более генерализованном росте интенсивности тета-активности у испытуемых женского пола при использовании видеокадров, формирующих негативные эмоции.

Ключевые слова: фазические эмоции, электрическая активность коры головного мозга, тета-активность.

Zhuravlov Oleksandr, Goshko Ludmyla, Burban Liliya. Analysis of the Intensity of Cortical Electrical Activity in the Theta-band of EEG During Formation of the Phasic Emotions of Different Valence Depending on the Sex Factor. The article describes the results of cortical electrical activity in the theta-band EEG during the formation phase of emotions of different valences depending on the sex factor. Shown the presence of distinctive features in the overall organization of cortical electrogenesis in men and women in the induction of emotions that are more generalized increase in the intensity of theta-activity in female using video frames that inducting negative emotions.

Key words: phasic emotions, electrical activity of the cerebral cortex, theta activity.

Стаття надійшла до редколегії 28.01.2015 p.

УДК 591.133.13:577.118

Руслана Іскра, Оксана Слівінська, Олена Шатинська, Оксана Сварчевська, Оксана Сеньків, Андрій Пилипець

\title{
Метаболічні процеси в печінці щурів за експериментального діабету та впливу цитрату хрому
}

Установлено, що за умов додавання до раціону щурів зі стрептозотоцин-індукованим діабетом цитрату хрому в кількостях 10 і 25 мкг Сr/кг маси тіла зростає активність лактатдегідрогенази, глюкозо-6-фосфатдегідрогенази, каталази, глутатіонпероксидази, уміст відновленого глутатіону та знижується вміст продуктів пероксидного окиснення ліпідів у печінці.

Ключові слова: щурі, цитрат хрому, експериментальний діабет, печінка.

(ㄷ Іскра Р., Слівінська О., Шатинська О., Сварчевська О., Сеньків О., Пилипеиьь А., 2015 
Постановка наукової проблеми та її значення. Цукровий діабет (ЦД) - одна 3 найважливіших проблем сьогодення, що зумовлено його поширенням, клінічним поліморфізмом і тяжкістю ускладнень. При ЦД спостерігаємо поліорганні ушкодження, у тому числі ураження печінки, яка є центральним органом, що забезпечує нормальний перебіг метаболічних процесів в організмі. Порушення функціонального стану печінки при цукровому діабеті трапляється часто й зумовлено здебільшого зниженням запасів глікогену в гепатоцитах і їх жировим переродженням [7]. Низка захворювань печінки супроводжується змінами вуглеводного обміну, основа яких - кисневе голодування клітин та порушення мікроциркуляції. У подальшому спостерігаємо клітинну деструкцію з ураженням мітохондрій і зниженням інтенсивності окисного фосфорилювання. Печінка відіграє значну роль в обміні мінеральних речовин, у тому числі мікроелементів, зокрема хрому (III), який необхідний для нормального функціонування вуглеводного, ліпідного й білкового обмінів в організмі людей $\mathrm{i}$ тварин [3]. Мета дослідження - 3'ясувати вплив різних кількостей цитрату хрому на метаболічні процеси в печінці щурів за експериментального цукрового діабету.

Аналіз досліджень із цісї проблеми. Мікроелемент хром (III) проявляє свою біологічну дію здебільшого через інсулін, тому за його дефіциту в організмі виникають метаболічні зміни, симптоми яких подібні до цукрового діабету $[11 ; 16]$. Дефіцит хрому підвищує інсулінорезистентність один з основних механізмів розвитку цукрового діабету другого типу, тоді як додаткове споживання цього елементу (окремо чи в поєднанні з вітамінами-антиоксидантами С i E) викликає зниження рівня глюкози в крові, НbA1с та інсулінорезистентність [12].

Методика досліджень. Дослідження проведено на 28 білих лабораторних щурах, які перебували в умовах віварію й мали масу тіла 150-170 г та були розділені на чотири групи: I - контрольна, II, III i IV - дослідні. Тваринам III і IV дослідних груп, на противагу II, до основного раціону протягом місяця від початку досліджень додавали розчин цитрату хрому (10 і 25 мкг Cr/кг маси тіла). Після цього у тварин усіх дослідних груп на тлі 24-годинного голодування викликали експериментальний цукровий діабет шляхом внутрішньоочеревинного уведення стрептозотоцину («Sigma», США) із розрахунку 35 мг/кг маси тіла. Гіперглікемію виявляли, застосовуючи вимірювання глюкози крові, зібраної з хвостової вени, за допомогою портативного глюкометра («Gamma-M»). Тварин виводили $з$ експерименту шляхом декапітації за легкого ефірного наркозу відповідно до етичних принципів експериментів на тваринах, ухвалених положеннями Європейської конвенції про захист хребетних тварин, які використовуються для експериментальних та інших наукових цілей.

У гомогенатах тканини печінки визначали активність супероксиддисмутази (СОД) [10], каталази [6], глутатіонпероксидази (ГПО) [8], глутатіонредуктази (ГР), уміст відновленого глутатіону (ВГ), гідропероксидів ліпідів (ГПЛ) і ТБК-активних речовин, а також активність глюкозо-6-фосфатдегідрогенази (Г-6-ФДГ) і лактатдегідрогенази (ЛДГ) [1].

Одержані цифрові дані обробляли статистично за допомогою комп’ютерної програми «Statistika». Для визначення вірогідних відмінностей між середніми величинами використовували критерій Стьюдента.

Виклад основного матеріалу та обгрунтування отриманих результатів досліджень. У тканині печінки щурів за умов експериментального діабету (II дослідна група) виявлено вірогідне зростання на 25,2 \% умісту ТБК-активних продуктів відносно тварин контрольної групи й незначне зростання вмісту ГПЛ (табл. 1). Високий уміст продуктів ПОЛ у тканині печінки щурів за відсутності хрому, очевидно, пов'язаний із послабленням зв'язування інсуліну з рецепторами на поверхні клітини. Це призводить до гіперболічної дії антагоніста інсуліну - кортизолу, який посилює процеси пероксидації ліпідів і, відповідно, пригнічує функціонування системи антиоксидантного захисту [17]. Проте уведення цитрату хрому до раціону щурів у кількостях 10 та 25 мкг $\mathrm{Cr} /$ кг м. т. призводило до зниження продуктів ПОЛ у тканині печінки. Однак вірогідно нижчий рівень ГПЛ (на 21,6 \%) виявлено лише в печінці тварин IV дослідної групи, порівняно з II-ю.

Наші дослідження узгоджуються 3 даними інших дослідників, у яких добавки хрому до раціону тварин призводять до послаблення процесів пероксидації ліпідів і посилення дії інсуліну $[4 ; 5 ; 13 ; 18]$, що, можливо, зумовлено активацією інсулінових рецепторів на мембранах клітин [14]. 
Уміст продуктів ПОЛ у тканині печінки щурів з експериментальним діабетом за впливу цитрату хрому $(\mathrm{M} \pm \mathrm{m} ; \mathrm{n}=7)$

\begin{tabular}{|c|c|c|c|c|}
\hline \multirow{2}{*}{ Показник } & $\begin{array}{c}\text { Контрольна } \\
\text { група }\end{array}$ & \multicolumn{3}{|c|}{ Дослідні групи } \\
\cline { 2 - 5 } & I & II & III & IV \\
\hline ГПЛ, ОЕ/ г тканини & $0,440 \pm 0,029$ & $0,595 \pm 0,049$ & $0,523 \pm 0,046$ & $0,466 \pm 0,032^{\#}$ \\
\hline $\begin{array}{c}\text { ТБК-активні продукти, } \\
\text { нмоль/г тканини }\end{array}$ & $34,20 \pm 1,94$ & $42,82 \pm 2,38^{*}$ & $39,70 \pm 1,95$ & $37,70 \pm 3,71$ \\
\hline
\end{tabular}

Інтенсивність вільнорадикального окиснення в організмі залежить від багатьох чинників, але, насамперед, детермінується злагодженим функціонуванням ензимів антиоксидантної системи (АОС). Одним із найважливіших ензимів АОС є СОД, яка каталізує реакцію дисмутації супероксидних аніон-радикалів і перетворює їх на молекули пероксиду гідрогену, що $є$ менш реакційно здатними. Однак під час дослідження активності СОД у тканині печінки щурів з експериментальним діабетом за впливу цитрату хрому нами не простежено вірогідних змін (табл. 2).

Табличя 2

Активність ензимів АОС у тканині печінки щурів з експериментальним діабетом за впливу цитрату хрому $(M \pm m ; n=7)$

\begin{tabular}{|c|c|c|c|c|}
\hline \multirow{2}{*}{ Показник } & \multirow{2}{*}{$\begin{array}{c}\begin{array}{c}\text { Контрольна } \\
\text { група }\end{array} \\
\text { I } \\
\end{array}$} & \multicolumn{3}{|c|}{ Дослідні групи } \\
\hline & & II & III & IV \\
\hline $\begin{array}{c}\text { СОД, } y м . \text { од/мг } \\
\text { протеїну }\end{array}$ & $23,09 \pm 0,81$ & $25,39 \pm 1,31$ & $25,43 \pm 1,34$ & $23,56 \pm 1,55$ \\
\hline $\begin{array}{c}\text { КА, ммоль/хв•мг } \\
\text { протеїну }\end{array}$ & $18,78 \pm 1,47$ & $14,74 \pm 0,76^{*}$ & $18,11 \pm 1,19^{\#}$ & $21,50 \pm 1,93^{\# \#}$ \\
\hline $\begin{array}{c}\text { ГПО, нмоль/хв } \\
\text { протеїну } \\
\end{array}$ & $21,62 \pm 1,28$ & $17,11 \pm 0,97 *$ & $21,21 \pm 1,60^{\#}$ & $23,56 \pm 2,27^{\#}$ \\
\hline $\begin{array}{c}\text { ГР, мкмоль/хв•мг } \\
\text { протеїну }\end{array}$ & $5,12 \pm 0,69$ & $4,03 \pm 0,76$ & $5,00 \pm 0,62$ & $5,04 \pm 0,69$ \\
\hline ВГ, млмоль/2 тканини & $1,16 \pm 0,075$ & $0,92 \pm 0,079^{*}$ & $1,16 \pm 0,066^{\#}$ & $1,23 \pm 0,064^{\#}$ \\
\hline
\end{tabular}

Примітка. У цих і наступних таблицях: *p $<0,05, * *$ p $<0,01, * * * p<0,001$ - вірогідність показників II, III, IV груп, порівняно з I групою; ${ }^{\#}<<0,05,{ }^{\text {\# }}$ p $<0,01,{ }^{\# \# ~}$ p $<0,001$ - вірогідність показників III, IV груп, порівняно з II групою.

Знешкодження пероксиду водню, що утворюється в результаті дисмутації супероксидного радикалу здійснює каталаза. Виявлено вірогідне зниження ії активності в тканині печінки тварин II дослідної групи на $21,5 \%$, порівняно з контролем. Зниження активності ензиму в тканині печінки діабетичної групи щурів указує на згубний вплив, який спричиняє комулювання супероксидних радикалів $\left(\mathrm{O}_{2}^{-}\right.$, $)$і пероксиду гідрогену $\left(\mathrm{H}_{2} \mathrm{O}_{2}\right)$ у цій тканині [19]. У тварин III та IV дослідних груп простежено вірогідне зростання активності каталази відносно II групи, відповідно, на 22,8 і 45,8 \%.

При оксидативному стресі особливо важлива глутатіонова система, яка безпосередньо знешкоджує активні форми оксигену або, як «друга лінія захисту» після СОД і каталази, доповнює й завершує роботу «першої лінії» та виправляє ії похибки [2; 9].

Досліджуючи ГПО в тканині печінки тварин II дослідної групи, порівняно 3 контрольною, спостерігаємо вірогідне зниження їі активності на 20,8 \%. При споживанні цитрату хрому щурами III й IV дослідних груп активність цього ензиму в тканині печінки зростала, відповідно, на 23,9 і 37,6 \%, порівняно з II групою.

Активність ГПО залежить від умісту ВГ, внутрішньоклітинну концентрацію якого підтримує ГР. Однак активність ГР у тканині печінки тварин за експериментального діабету та впливу цитрату хрому вірогідно не змінювалася.

У дослідженнях установлено зниження вмісту ВГ на 20,7 \% у тканині печінки тварин II дослідної групи, порівняно з контрольною. Однак у тканині печінки тварин III та IV дослідних груп уміст ВГ 
був вірогідно вищий відносно II дослідної групи (відповідно, на 26,0 і 33,0 \%). Крім того, варто зауважити, що саме в печінці синтезується й відновлюється основний пул ВГ організму.

Додаткове уведення цитрату хрому в раціон щурів 3 експериментальним діабетом сприяло зростанню активності досліджуваних ензимів АОС до рівня контролю. Очевидно, це зумовлено опосередкованою дією елемента через гормон інсулін на антиоксидантні ензими організму тварин. Отримані результати певною мірою узгоджуються з даними інших дослідників, котрі вказують на активацію АОС при додатковому уведенні сполук хрому до раціону тварин $[15,20]$. Водночас за умов цукрового діабету спостерігаємо енергетичне виснаження організму, що зумовлює виникнення дефіциту енергетичних субстратів, що прямо пропорційно впливає на ефективність захисних систем, зокрема антиоксидантної.

Установлено, що після надходження вуглеводної їжі близько $55 \%$ глюкози захоплюється печінкою. У ії клітини глюкоза надходить за допомогою дифузії, оскільки мембрана їхня проникна для глюкози. Інсулін підвищує поглинання глюкози печінкою завдяки індукції синтезу печінкового ензиму глюкокінази. У клітини цієї тканини глюкоза метаболізується як по шляху гліколізу, так і по пентозофосфатному.

У дослідженнях установлено, що активність ЛДГ у тканині печінки різко знижувалася в II дослідній групі (на 64,9 \% відносно контрольної) (табл. 3). Проте у тварин III та IV дослідних груп активність ензиму зростала, порівняно з ІІ групою (відповідно, на 135,6 і 155,1 \%). Зростання активності ЛДГ у тканині печінки може свідчити про активацію і аеробних, i анаеробних шляхів гліколізу в ній, оскільки в цій тканині переважають гібридні фракції ізоензимів. У клітинах печінки здійснюється координована регуляція гліколізу й глюконеогенезу відповідно до фізіологічних потреб усього організму. Однак за цукрового діабету може інтенсивно відбуватися глюконеогенез 3 амінокислот.

Таблиия 3

Активність ензимів вуглеводного обміну в тканині печінки щурів з експериментальним діабетом за впливу цитрату хрому $(M \pm m ; n=7)$

\begin{tabular}{|c|c|c|c|c|}
\hline \multirow{2}{*}{ Показник } & $\begin{array}{c}\text { Контрольна } \\
\text { група }\end{array}$ & \multicolumn{3}{|c|}{ Дослідні групи } \\
\hline & I & II & III & IV \\
\hline $\begin{array}{c}\text { ЛДГ, } \\
\text { нмоль/хв •мГ протеїну }\end{array}$ & $1,425 \pm 0,168$ & $0,499 \pm 0,091 * * *$ & $1,176 \pm 0,161^{\# \#}$ & $1,273 \pm 0,133^{\# \#}$ \\
\hline $\begin{array}{c}\text { Г-6-ФДГ, } н \\
\text { моль/хв •мг протеїну }\end{array}$ & $1,502 \pm 0,460$ & $0,981 \pm 0,311$ & $1,827 \pm 0,202^{\#}$ & $1,541 \pm 0,124$ \\
\hline
\end{tabular}

Стосовно Г-6-ФДГ ії активність дещо знижувалася в тканині печінки тварин II дослідної групи, порівняно з контрольною, однак вірогідно зростала на 21,6 \% у III групі відносно II. Потрібно зауважити, що печінка відрізняється від інших тканин значною потребою в НАДФН (які синтезуються в ПФШ), зокрема для синтезу жирних кислот. Однак активність Г-6-ФДГ гальмується продуктом реакції - НАДФН. Отже, інтенсивність ПФШ залежить від швидкості використання НАДФН у реакціях анаболізму й контролюється відношенням у клітині НАДФ ${ }^{+} / \mathrm{HАДФН.}$

Зростання активності дегідрогеназ вуглеводного обміну в тканині печінки щурів з ЕЦД за впливу цитрату хрому, очевидно, відбувається за рахунок наявності достатньої кількості глюкози всередині гепатоцитів та стимуляції синтезу молекул цих ензимів за дії хрому.

Висновки та перспективи подальших досліджень. За умови додавання до раціону щурів 3 експериментальним цукровим діабетом цитрату хрому в кількостях 10 і 25 мкг $\mathrm{Cr} /$ кг маси тіла в тканині печінки зростає активність лактатдегідрогенази, глюкозо-6-фосфатдегідрогенази, каталази, глутатіонпероксидази, уміст відновленого глутатіону й знижується вміст продуктів пероксидного окиснення ліпідів. Це свідчить про інтенсифікацію вуглеводного обміну та активацію АОС у печінці щурів із діабетом під дією хрому(III).

У перспективі планується дослідження синтезу жирних кислот у печінці щурів з експериментальним цукровим діабетом під впливом цитрату хрому. 


\section{Джсерела та література}

1. Довідник: фізіолого-біохімічні методи досліджень біології, тваринництві та ветеринарній медицині. Вид. 3-тє, переробл. і доповн.) / під ред. В. В. Влізло та ін. - Львів : [б. в.], 2004. - 399 с.

2. Іванушко Я. Г. Вплив рентгенівського випромінення на ферменти антиокиснювального захисту печінки щурів / Я. Г. Іванушко, Ю. П. Гриневич, А. І. Липська // Ядерна фізика та енергетика. - 2009. №10 (1). - С. 76-79.

3. Іскра Р. Я. Біохімічні механізми дії хрому в організмі людини і тварини / Р. Я. Іскра, В. Г. Янович // Укр. біохімічний журн. - 2011. - Т. 83, № 5. - С. 5-12.

4. Іскра Р. Я. Біологічна роль хрому в організмі тварин / Р. Я. Іскра, В. В. Влізло // Біологія тварин. - 2011. Т.13, № 1-2. - С. 69-71.

5. Іскра Р. Я. Методи оцінки системи антиоксидант захисту організму тварин за дії сполук хрому : метод. рек. / Р. Я. Іскра. - Львів : [б. в.], 2011. - 35с.

6. Королюк М. А. Метод определения активности каталазы / М. А. Королюк, И. Г. Иванова, И. Г. Майорова // Лаб. дело. - 1988. - № 1. - С. 16-18.

7. Мерецький В. М. Порушення ліпідного та вуглеводного обміну і методи їх корекції при експериментальному цукровому діабеті / В. М. Мерецький // Медична хімія. - 2007. - Т. 9, № 3. - С. 83-86.

8. Моин В. М. Простой и специфический метод определения активности глутатион-пероксидазы в эритроцитах / В. М. Моин // Лаб. дело. - 1986. - № 12. - С. 124-126.

9. Сибірна Н. О. Дослідження окремих біохімічних показників за умов оксидативного стресу : навч.метод. посіб. / Н. О. Сибірна, О. М. Маєвська, М. Л. Барська // Львів : Вид. центр ЛНУ ім. І. Франка, 2006. $-60 \mathrm{c}$.

10. Чевари С. Определение антиоксидантных параметров крови и их диагностическое значение в преклонном возрасте / С. Чевари, Т. Д. Андял, Д. Штиренгер // Лаб. дело. - 1991. - № 10. - С. 9-13.

11. Anderson R. A. Nutritional factors influencing the glucose/insulin system: Chromium / R. A. Anderson // Journal of American College Nutrition. - 1997 - V. 16. - P. 404-410.

12. Cefalu W. T. Role of Chromium in Human Health and in Diabetes / W. T. Cefalu, F. B. Hu // Diabetes Care. 2004. - V. 27, N 11. - P. 2741-2751.

13. Chromium picolinate supplementation attenuates body weight gain and increases insulin sensitivity in subjects with type 2 diabetes / [J. Martin, Z. Q. Wang, X. H. Zhang et al] // Diabetes Care. - 2006. - V. 29. - P. $1826-1832$.

14. Effect of supplemental chromium on patients with symptoms of reactive hypoglycemia [R. A. Anderson, M. M. Polansky, N. A. Bryden et al.] // Metabolism. - 1987. - V. 36. - P. 351-355.

15. Guerrero-Romero F. Complementary Therapies for Diabetes: The case for chromium, Magnesium, and Antioxidants / F. Guerrero-Romero, M. Rodriguez-Moran // Archives of Medical Research. - 2005. - Vol. 36. P. 250-257.

16. Ming-Hoang L. Antioxidant Effects and Insulin Resistance Improvement of Chromium Combined with Vitamin C and E Supplementation for Type 2 Diabetes Mellitus // Clin. Biochem. Nutr. - 2008. - Vol. 43. - P. 191-198.

17. National Research Council (NRC). The role of chromium in animal nutrition. - National Washington : Academy Press, DC, 1995.

18. Reversal of corticosteroid-induced diabetes mellitus with supplemental chromium / [A. Ravina, L. Slezak, N. Mirsky et al.] // Diabetic Medicine. - 1999. - V.16. - P. 164-167.

19. Satheesh M. A. Antioxidant effect of Boerhavia diffuse L in tissues of alloxan induced diabetic rats / M. A. Satheesh, and L. Pari // Indian J.Exp. Biol. - 2004. - Vol. 42. - P. 989-992.

20. Suzan M. Chromium Picolinate and Rossiglitazone Improve Biochemical Derangement in a Rat Model of Inulin Resistance. Role of TNF-£ and Leptin / M. Suzan et al. // Pharmacologia. - 2013. - Vol. 4(3). - P. $186-196$.

Искра Руслана, Сливинская Оксана, Шатинськая Елена, Сварчевськая Оксана, Сенькив Оксана, Пилипец Андрей. Метаболические процессы в печени крыс при экспериментальном диабете и влиянии цитрата хрома. При сахарном диабете наблюдается энергетическое истощение организма, что приводит к возникновению дефицита энергетических субстратов, прямо пропорционально влияет на эффективность функционирования антиоксидантной системы. В ткани печени крыс в условиях экспериментального диабета установлено достоверное повышение содержания ТБК-активных продуктов, снижение активности каталазы, глутатионпероксидазы, лактатдегидрогеназы и содержания восстановленного глутатиона. При добавлении в рацион крыс цитрата хрома в количествах 10 и 25 мкг $\mathrm{Cr} /$ кг массы тела исследуемые показатели в ткани печени достигают уровня животных контрольной группы, а по отношению к животным с экспериментальным диабетом повышается активность лактатдегидрогеназы, глюкозо-6-фосфатдегидрогеназы, каталазы, глутатионпероксидазы, содержание восстановленного глутатиона, однако снижается содержание продуктов перекисного окисления липидов.

Ключевые слова: крысы, цитрат хрома, экспериментальный диабет, печень. 
Iskra Ryslana, Slivinska Oksana, Shatynska Olena, Svarchevska Oksana, Senkiv Oksana, Pulipez Andriy. Metabolic Processes in rats' Liver Under the Condition of Experimental Diabetes and Chromium Citrate Influence. Under the condition of diabetes mellitus an energetic exhaustion of organism is observed, which leads to the deficiency of energetic substrates and it affects the effectiveness of antioxidant system functioning in direct proportion. Under the condition of experimental diabetes credible increase of MDA content, decrease of catalase, glutathione peroxidase, lactate dehydrogenase activities and the content of reduced glutathione were established in liver tissue of rats. After the addition of chromium citrate in a quantity of 10 and $25 \mathrm{mcg} \mathrm{Cr}_{3}{ }^{+} / \mathrm{kg}$ body weight to the diet of rats those researched indexes reach to their levels in the control group, while activities of lactate dehydrogenase, glucose-6-phosphate dehydrogenase, catalase, glutathione peroxidase and the content of the reduced glutathione increase compared to rats with experimental diabetes, although the content of lipid peroxidation products decrease.

Key words: rats, chromium citrate, experimental diabetes, liver.

Стаття надійшла до редколегії 28.01.2015 p.

УДК 612.172-055.25

\author{
Тетяна Качинська, \\ Ольга Абрамчук, \\ Оксана Поліщук, \\ Юлія Шершень
}

\section{Особливості часових показників варіативності серцевого ритму в дівчат різного шкільного віку під час виконання когнітивних завдань}

Вивчено часові показники ВСР у дівчат різного шкільного віку під час розумового навантаження. В осіб середнього шкільного віку виконання когнітивних завдань супроводжувалося більшим психоемоційним напруженням організму, компенсованим дисстресом та переважанням симпатичного рівня регуляції в серцевій діяльності.

Ключові слова: варіативність серцевого ритму, дисстрес, ваготонія, симпатикотонія.

Постановка наукової проблеми та ії значення. Для сучасного етапу розвитку суспільства характерне збільшення потоку інформації, що є причиною зростання психоемоційного напруження та загального рівня гіпокінезії тощо [7, с. 73-76]. Численні дослідження свідчать, що умови антропогенного навантаження приводять до більш інтенсивного використання адаптаційних можливостей організму. Відомо, що здоров’ я людини характеризується не лише відсутністю патологічно змінених органів і систем, але й функціональними резервами, які забезпечують ефективну адаптацію до мінливих умов середовища. Установлено, що функціональні резерви організму людини значною мірою визначаються резервами регуляції [1, с. 473-496].

Аналіз досліджень цієї проблеми. Варіабельність серцевого ритму (ВСР) - універсальна фізіологічна властивість, яка не лише відображає стан вегетативної нервової системи, але і $є$ показником регуляторних процесів на рівні цілісного організму [1, с. 473-496], відображає стан його адаптаційних резервів та резервів здоров’я. ВСР дає змогу виявити особливості регуляторних механізмів серця під час фізичних навантажень в осіб із різними типами гемодинаміки, є чутливим показником оцінки ризику розвитку захворювань [6, с. 66-72], свідчить про рівень аеробного метаболізму [5, с. 48-67], пов’ язана 3 максимальною аеробною потужністю й складом тіла [10, с. 2304-2310]. Утановлено: ВСР знижується 3 появою надлишкової маси та розвитком ожиріння в дітей [9], а також відображає особливості статевого розвитку й перебігу фаз менструального циклу [3, с. 300-305].

Організм підлітків через незавершеність морфофункціонального розвитку [11, с. 269-273], недосконалість його регуляторних механізмів, високу лабільність гостро реагує на впливи несприятливих факторів [2, с. 18-24]. У науковій літературі визнано, що соматотип є морфогенетичним маркером, який регламентує особливості розвитку організму на різних етапах онтогенезу. Проте перебіг процесів регуляції в період росту й розвитку організму, залежно від інтенсивності когнітивного навантаження, у науковій літературі розкрито недостатньо. Тому мета роботи полягала у

(ㄷ Качинська Т., Абрамчук О., Поліщук О., Шершень Ю., 2015 